Trakia Journal of Sciences, Vol. 16, Suppl. 1, pp 154-157, 2018

Copyright (C) 2018 Trakia University Available online at:

ISSN 1313-7069 (print) http://www.uni-sz.bg

ISSN 1313-3551 (online)

doi:10.15547/tjs.2018.s.01.032

\title{
FLOODS AS DISASTERS - PUBLIC HEALTH CHALLENGES
}

\author{
D. Dimitrova*
}

\author{
Department of Preventive Medicine, FPH, MU-Sofia, Bulgaria
}

\begin{abstract}
According to WHO data, floods are the most common natural disasters. Every year about 1 billion people in more than 150 countries are at risk. In Bulgaria over 280000 people live in flood-prone areas (4\%). According to NSI and MoI data after 2010, about 3000 floods are registered in Bulgaria, the damage is over 160000 leva, and for recovery - over 170 million. The purpose of the study is to analyze the public health challenges due to floods. Methods. Statistical survey about disasters on the territory of the country. Analysis of the database for flooding in Bulgaria from 1990 to 2014. Results. In the last three decades, an average of more than 100 million people in the world are affected by floods. The frequency of floods and their mortality rate for the country over the specified period is over $47 \%$. Conclusions. According to the analysis, the number of floods is increasing. Primary, secondary and long-term health effects are significant. Casualties are mainly: hypothermia, traumatism, drowning. There is a risk of infectious diseases. Flood risk reduction, optimization of protection and good practical training for teams is the effective direction for the development of public health.
\end{abstract}

Key words: floods; disasters; casualties; public health; Bulgaria

\section{INTRODUCTION}

According to WHO data, floods are the most common natural disasters. Every year about 1 billion people in more than 150 countries are at risk. At present, about 20 million people are at risk of flooding (90 billion Euro). (1-16) The new risk assessments show that only 15 years (by 2030) the estimated growth is 50 million affected (470 billion Euro). In Bulgaria over 280000 people live in flood-prone areas (4\%). According to NSI and MoI data after 2010, about 3000 floods are registered in Bulgaria, the damage is over 160000 leva, and for recovery - over 170 million. (Tables $\mathbf{1 , 2})(1-5$, $7,9-15)$ Flooding is the No. 1 natural disaster in the United States. (14-16)

\section{PURPOSE}

The purpose of the study is to analyze the public health challenges due to floods.

\section{METHODS .}

A database of NSI, MoI for catastrophic floods (CF) has been applied and analyzed. Scope - CF on the territory of the country. The medical casualties analysis covers a period from 1974 to 2016 (1974-2006; 2010-2016)

\footnotetext{
* Correspondence to: Dimitrova D., Department of Preventive Medicine, FPH, MU-Sofia, Bulgaria, Bulgaria, 1527, Sofia, Byalo more st., 8, Tel. 0889256810
}

Statistical units of the study - the CF, medical casualties. Unit of measure - number and relative share. Frequency - annual report. The study is exhaustive and no estimates are made. A descriptive, retrospective and comparative analysis of the share of medical casualties among the population in the country

\section{RESULTS}

In the last three decades, an average of more than 100 million people in the world are affected by floods. According to NSI data, the significant floods in the country (2010-2013) occupy the third place after the fires and crashes during the last five years and prevail in the Black Sea region (15\% of the country). ( 7 , $11,15)$ The statistics presented in the National Program for Protection of Disasters 2009-2013 show that in Bulgaria the highest relative share of natural disasters are the floods $(54.2 \%)$, followed by landslides ( $22 \%)$, storms, tornadoes, smirch, whirlwind (18.2\%). (Table 1) $(1-6,14)$

In 2014, more than 18 people died in the flood. Between 25 May and 25 September 2005, more than $80 \%$ of the country's territory is affected by floods, with more than 3200000 inhabitants, of which 2 million people are directly affected. Human victims are over 20, and the damages amount to 890 million Leva. (Table 2) $(7,11)$ 
Table 1. Absolute flood numbers in Bulgaria for 2010 - 2016 (NSI)

\begin{tabular}{|c|c|c|c|c|c|c|c|}
\hline \multirow{2}{*}{ Crisis events } & \multicolumn{7}{|c|}{ Crisis events - in numbers } \\
\hline & 2010 & 2011 & 2012 & 2013 & 2014 & 2015 & 2016 \\
\hline Total & 4571 & 8268 & 10826 & 2728 & 4356 & 4008 & 3577 \\
\hline Fires & 1630 & 2185 & 3010 & 764 & 2245 & 2474 & 2448 \\
\hline Landslides & 59 & 76 & 72 & 51 & 75 & 125 & 71 \\
\hline Earthquakes & 12 & 4 & 22 & 6 & 4 & 1 & 2 \\
\hline Droughts & 6 & 30 & 23 & 3 & 1 & - & - \\
\hline Floods & 651 & 382 & 692 & 547 & 360 & 266 & 184 \\
\hline $\begin{array}{l}\text { Storms, tornado, } \\
\text { windspout, whirlwind }\end{array}$ & 47 & 48 & 528 & 89 & 14 & 12 & 29 \\
\hline Hailstorms & 16 & 13 & 14 & 13 & 8 & 21 & 5 \\
\hline Snowstorms (snowfall) & 103 & 94 & 93 & 50 & 26 & 56 & 87 \\
\hline Icings, frosts & 18 & 134 & 186 & 20 & 3 & 7 & 2 \\
\hline Accidents & 7 & 24 & 312 & 314 & 76 & 33 & 1 \\
\hline Accidents with vehicles & 1937 & 5218 & 5858 & 841 & 1530 & 994 & 734 \\
\hline $\begin{array}{l}\text { Pollutions (with } \\
\text { chemical materials, } \\
\text { dangerous waste, } \\
\text { municipal waste and } \\
\text { other) }\end{array}$ & 45 & 42 & 7 & 19 & 3 & 8 & 5 \\
\hline $\begin{array}{l}\text { Epidemic human } \\
\text { diseases }\end{array}$ & 12 & 7 & 7 & 6 & 3 & 5 & 4 \\
\hline $\begin{array}{l}\text { Epidemic animal } \\
\text { diseases (incl. birds) }\end{array}$ & 5 & 2 & - & 1 & 6 & 2 & 3 \\
\hline Calamity & 21 & 9 & 2 & 2 & 1 & 2 & - \\
\hline
\end{tabular}

${ }^{1}$ The data are obtained on the basis of the annual reports submitted by the municipal administrations, as follows: for 2010 from 119, for 2011 from 127, for 2012 by 128, for 2013 by 100, for 2014 by 141, for 2015 by 115 and for 2016 of 83 municipal administrations.

Table 2. Losses by crisis events in 2016 - total for the country ${ }^{1}$

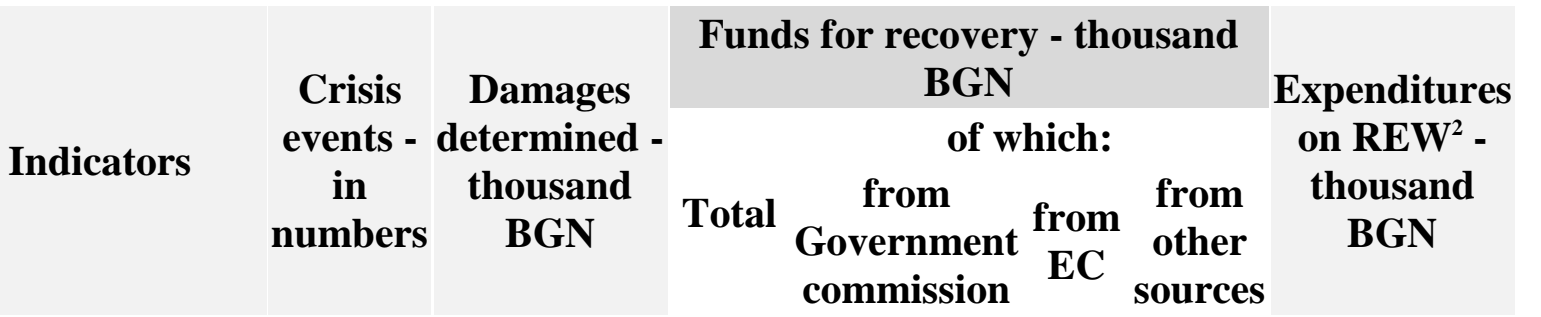

$\begin{array}{lllllllll}\text { Total } & 3577 & 65243 & 2070917635 & 1583 & 1242 & 23 \\ \text { Fires } & 2448 & 1061 & 11 & - & - & - & 6 \\ \text { Landslides } & 71 & 9632 & 3791 & 3357 & 234 & 200 & 468 \\ \text { Earthquakes } & 2 & - & - & - & - & - & - \\ \begin{array}{l}\text { Droughts } \\ \text { Floods }\end{array} & - & - & - & - & - & - & - \\ \begin{array}{l}\text { Storms, tornado, } \\ \text { windspout, }\end{array} & \mathbf{1 8 4} & \mathbf{3 0 6 1 7} & \mathbf{5 7 7 8} & \mathbf{4 1 7 5} & \mathbf{1 3 4 9} \mathbf{2 4 2} & \mathbf{2} 215 \\ \begin{array}{l}\text { whirlwind } \\ \text { Hailstorms }\end{array} & 29 & 3267 & 186 & - & - & - & 117 \\ \begin{array}{l}\text { Snowstorms } \\ \text { (snowfall) }\end{array} & 8 & 10 & - & - & - & - & - \\ \text { Icings, frosts } & 2 & 2 & - & - & - & - & 157 \\ \end{array}$


Table 2. Losses by crisis events in 2016 - total for the country ${ }^{l}$

\begin{tabular}{|c|c|c|c|c|c|c|c|}
\hline \multirow{3}{*}{ Indicators } & \multirow{3}{*}{$\begin{array}{l}\text { Crisis } \\
\text { events - } \\
\text { in } \\
\text { numbers }\end{array}$} & \multirow{3}{*}{$\begin{array}{l}\text { Damages } \\
\text { determined - } \\
\text { thousand } \\
\text { BGN }\end{array}$} & \multicolumn{4}{|c|}{$\begin{array}{c}\text { Funds for recovery - thousand } \\
\text { BGN }\end{array}$} & \multirow{3}{*}{$\begin{array}{c}\text { Expenditures } \\
\text { on REW }{ }^{2} \text { - } \\
\text { thousand } \\
\text { BGN }\end{array}$} \\
\hline & & & \multicolumn{4}{|c|}{ of which: } & \\
\hline & & & Total & $\begin{array}{c}\text { from } \\
\text { Government } \\
\text { commission }\end{array}$ & $\begin{array}{c}\text { from } \\
\text { EC }\end{array}$ & $\begin{array}{c}\text { from } \\
\text { other } \\
\text { sources }\end{array}$ & \\
\hline Accidents & 1 & 9 & - & - & - & - & 9 \\
\hline $\begin{array}{l}\text { Accidents with } \\
\text { vehicles }\end{array}$ & 734 & 20052 & 10943 & 10103 & - & 800 & 20204 \\
\hline $\begin{array}{l}\text { Pollutions (with } \\
\text { chemical } \\
\text { materials, } \\
\text { dangerous waste, } \\
\text { municipal waste } \\
\text { and other) }\end{array}$ & 5 & 1 & - & - & - & - & - \\
\hline $\begin{array}{l}\text { Epidemic human } \\
\text { diseases }\end{array}$ & 4 & - & - & - & - & - & - \\
\hline $\begin{array}{l}\text { Epidemic animal } \\
\text { diseases (incl. } \\
\text { birds) }\end{array}$ & 3 & 1 & - & - & - & - & - \\
\hline Calamity & 2 & 240 & - & - & - & - & 1 \\
\hline $\begin{array}{l}\text { Other crisis, } \\
\text { natural disasters } \\
\text { and events }\end{array}$ & - & - & - & - & - & - & - \\
\hline
\end{tabular}

\footnotetext{
${ }^{1}$ Data are based on the annual reports presented in NSI

by 83 municipal administrations.

${ }^{2} \mathrm{R} \mathrm{E} \mathrm{W} \mathrm{-} \mathrm{rescue} \mathrm{and} \mathrm{emergency} \mathrm{work.}$

30.11.2017
}

Annually, $40 \%$ of the victims of natural disasters are from the $\mathrm{CF}$ according to WHO. The frequency of floods and their mortality rate for the country over the specified period is over $47 \% .(1,7,11,12,15)$

Over the past two weeks due to the heavy rainfall (for the day to 30-50 1/sq.m) of Athens and Sithonia in Greece; in Sofia, Montana, Roman (orange code in 9 regions of the country) in Bulgaria are subject to local floods with serious material damage.

The consequences of catastrophic floods among the affected population are: short-term and long-term; primary and secondary; secondary disasters - landslides, epidemics. Compromise adjacent ecosystems. Among the injured people stand out: drowning; ARF; hypothermia; traumatism; shock; electric shock; vector transmissible diseases, cholera, etc. $(3-6,8,9)$

\section{DISCUSSIONS}

Due to the serious nature of flood damage, health impacts and to optimize prevention and reduce risk, 163 simulation models of floods in catchments and settlements in the country have been prepared. Risk management is planned in three stages $(7,14,16)$ :

Phase I - Preliminary Flood Risk Assessment (PFRA)

Stage II - Threat and flood risk maps

Phase III - Flood Risk Management Plans

The National Flood Program aims to reduce the impact of flooding on private and public structures. It does so by providing affordable plan to property owners, renters and businesses and by encouraging communities to adopt and enforce floodplain management regulations. (14-16) Data is used to improve general understanding of flood risk perceptions, inform community engagement strategies, and evaluate the Risk Mapping Assessment Planning (Risk MAP) program's 
progress in the identification, mitigation, and communication of risk. $(15,16)$

\section{CONCLUSIONS}

According to the analysis, the number of floods is increasing. Primary, secondary and long-term health effects are significant. Casualties are mainly: hypothermia, traumatism, drowning. There is a risk of infectious diseases. Flood risk reduction, optimization of protection and good practical training for teams is the effective direction for the development of public health.

\author{
Abbreviations \\ MC - Medical Casualties \\ GD"FSCP" - General Directorate "Fire Safety \\ and Civil Protection" \\ MoI - Ministry of Interior \\ NSI - National Statistical Institute \\ $\boldsymbol{M H}$ - Ministry of Health \\ $\boldsymbol{H} \boldsymbol{L}$ - Health Law \\ ARF - Acute Respiratory Failure \\ CF - Catastrophic Floods
}

\section{REFERENCES}

1. Action Program for Sustainable Flood Protection in the Danube Basin, ICRC Document IC / 082,

2. Bulgarian Infrastructure for Spatial Data, BIPD, 09.06.2018

\section{DIMITROVA D.}

3. Directive 2007/60 / EC, Art., On Flood Risk Assessment and Management for the Republic of Bulgaria

4. Flood Risk Management Plan of East Aegean River Basin District, Adopted by Council of Ministers Resolution No. 1109 / 29.12.2016

5. Flood Risk Management Plan (2016-2021)

6. Mardirosian G. 2002. Natural disasters, ecological catastrophes and their remote study, 2: 43

7. MoI data of floods in Bulgaria, 2018

8. $\mathrm{MH}$ data of victims of floods in Bulgaria, 2018

9. National flood protection plan. 2017

10.National Institute of Meteorology and Hydrology (NIMH) at the Bulgarian Academy of Sciences, 2018

11.NSI data of fires in Bulgaria, 2018

12.The World Resources Institute (WRI), database 2017

13. Strategy for the Development of Voluntary Formations for Protection against Disasters, Fires and Other Emergencies in the Republic of Bulgaria for the period 20122020.

14.UNISDR data of floods, 2017

15.WHO data of floods, 2018

16.https://www.fema.gov/flood-statistics 